\title{
Public Debt and Economic Growth in Tunisia: A Re-examination
}

\author{
Riadh Brini $^{1}$, Hatem Jemmali ${ }^{2, *}$, Arafet Ferroukh ${ }^{1}$ \\ ${ }^{1}$ Faculty of Economic Sciences and Management of Nabeul, University of Carthage, Tunisia \\ ${ }^{2}$ Faculty of Economic Sciences and Management of Sousse, University of Sousse, Tunisia
}

Copyright $\bigcirc 2016$ by authors, all rights reserved. Authors agree that this article remains permanently open access under the terms of the Creative Commons Attribution License 4.0 International License

\begin{abstract}
The aim of this paper is to examine the impact of public debt on economic growth in Tunisia over a period spanning around two decades (1990-2013). Using the Autoregressive distributed lag model (ARDL), the paper traces a long run equilibrium between public debt and economic growth. Besides, we used the Granger causality test to examine the direction of causality among various variables. The results show that public debt and total debt service have a negative and significant effect on economic growth in the long run. In the short and long run there is a unidirectional Granger causality between public debt and economic growth. We also find that there is a bidirectional Granger causality between total debt service and economic growth in the long run. While, there is no evidence of short run causality.
\end{abstract}

Keywords Public Debt, Total Debt Service, Economic Growth, ARDL

\section{Introduction}

In recent years, public debt has received considerable attention from governments, policymakers and scholars as well as international organizations (World Bank, International Monetary Fund...) due to its critical implications for a country's development. In Tunisia the continuous increase in government spending expands the gap of fiscal deficit, and thereby strength the government to depend on public debt. However, the Tunisian government tries to reduce the fiscal deficit by increasing external and internal public debt, which is likely to affect the economic growth of the country.

The main question of our study is do high levels of public debt reduce the short and long-run economic growth in Tunisia?

The economic literature indicated that public debt could have a negative effect on long-run economic growth through many channels. It may reduce the productivity of public expenditures [1], create anticipations of future financial repression and increase uncertainty [2], increase severing risk [3] and crowd out the private investment through increasing levels of interest rates [4]. However, Delong and Summers [5] suggest that expansionary fiscal policy that lead to high public debt and avoid economic protracted recessions, raise short and long term growth.

The debt overhung theories suggest that high public debt has an inverse linear relationship with economic growth. These results are in line with a several empirical literature which founds that there is a negative non-linear correlation between public debt and economic growth both across countries and a single country level analysis $[6,7,8]$.

In this paper, we examine particularly the effect of total public debt on economic growth in Tunisia. This study differs from the current literature in two ways. Firstly, it revisits the relationship between public debt and economic growth when the Tunisian economy has faced serious problems since 2011. The majority of the credit rating agencies have downgraded Tunisia's sovereign rating, which has created important fiscal pressure on the government. Secondly, this study uses the autoregressive distributed lag model (ARDL) to explore both short and long-run impacts of public debt on economic growth in Tunisia between 1990 and 2013.

This paper is organized as follows. In the next section, we conduct a literature review on public debt and economic growth relationship. The third section describes the data and methodology used. The fourth section presents the empirical results and the last section concludes with some recommendations.

\section{Literature Review}

In classical economics, public debt is viewed economically as a destructive factor $[9,10]$. Indeed, the Ricardian Equivalence theory, for instance considered that the financing of public spending through taxation and borrowing is equal. The partisans of this theory argued that 
the repayment of debt will take place through future taxes, which means persons will augment their earning by buying the bonds that have been issued by the government. Hence, according to the Ricardian theory, public debt hasn't any effect on economic growth.

While, in the Investment Saving-Liquidity Preference Money Supply (IS-LM) model, Keynesian economists argued that a rise in government debt resulting from deficit-financed fiscal policy will raise the level of income, the transaction demand for money and inflation rate. This will result in an increase in the rate of interest on bonds with a fixed money supply. Besides, the Keynesian theory noted that if the private sector recognizes government securities as net wealth, the shortfall will further augment private consumption spending, transaction demand, interest rates, and prices. So, the consequences of expansionary fiscal policy on capital formation may be reinforced through the accelerator effects and thus increase economic growth.

Alternatively, in monetary economics, monetarists have pointed out that the macroeconomic effect of debt financed is crowding out the private investment throughout rising levels of interest rates. Thus, public debt will have a negative effect on economic growth. In addition, the debt overhang theory assumed that if prospect debt exceeds the government's repayment capacity, the anticipated debt-service costs will discourage further local and foreign investment, and hence dampen economic growth.

In theoretical literature, the correlation between public debt and economic growth has gained the attention of a wide range of economists from various schools of thought. But few studies have focused on the empirical evidence, investigating the theoretical findings and discussions [11]. According to former authors, this lack of interest is due to several reasons such as: shortage of reliable and comparable datasets for public debt among countries; consideration that the public debt variable is a dependant rather than an independent variable which can be employed as a tool to manage and influence the macro-financial results and the fact that public debt has so far not been recognized as problematic issue owing to its relatively small size in most developed countries.

Despite all these handicaps and problems, some studies have shown a significant relationship between debt and economic growth. In this respect, Baro [12], and Camen and Rogoff [13] proved that public debt has a significant impact on economic growth in the United Kingdom. While, Forslund et al. [7] found a negative correlation between domestic debt and inflation in developing countries. Ismihan and Ozkan [14] in their paper showed that public debt can hurt economic growth in countries when the financial movement is underdeveloped.

Other studies, investigating the empirical evidence of the connection between total debt and economic growth have found a significant inverse linear relationship between these two variables both across countries and at a single country-level analysis. This is close to the baseline estimate of Westphal, Checherita and Rother [15] who found from their analysis of twelve European countries that there exists a non-linear relationship between public debt and economic growth, which was chiefly owing to private savings, public investment and total factor productivity. According to the analysis of Schclarek [6], who examined 59 developing countries from 1970 to 2002 a significant inverse relationship was shown too, between external debt and economic growth.

In this regard, the empirical evidence illustrates that beyond a certain threshold, higher government debt hurts potential economic growth, which may confirm a non-linear and concave (inverted U-shape) liaison between public debt and economic growth $[16,17,18,19,20]$. This means that these researches addresses that low levels of government debt may stimulate and at the same time increase economic growth. Reaching a certain level, an additional increase of the amount of these debts could affect negatively the economic growth of a country. But, in the majority of studies focused on developed countries facing the problem of an elevated and unsustainable level of public debt, we found that the empirical evidence on the transmission channels through which high debt is likely to have undesirable outcomes on economic growth is relatively limited.

Concerning the low-income countries, Clements, Nguyen, T. Q., Clements, M. B. J., and Bhattacharya, M. R. [21] found a nonlinear linkage between external debt and economic growth using a panel dataset of 55 under-developed countries over the time period 1970-1999. In their study, the authors estimated that the critical threshold, namely the turning point, in the net present value of external debt is in the range of $20 \%-30 \%$ of GDP. The main explanation of such nonlinear relationship is associated with the debt-overhang hypothesis defined by Krugman [22], whereby beyond a definite level of a threshold value debt has negative effects on growth caused by growing ambiguity to meet a country's debt servicing obligations. Accordingly, such increase of debt, which have harmful influences on investment motivations, added to decrease of the solvency of a country's repayment ability, diminish potential growth of a country in the short- and long-term.

Likewise, Pattillo, Poirson and Ricci [23], using a large panel dataset of 93 developing countries over the period 1969-1998, found a non-linear, Laffer-type relationship between the amount of external debt and economic growth. The authors suggested, in their study, that the main channel through which undue external indebtedness lowers economic growth is via the diminished efficiency of investments rather than the level of investment. Besides, Pattillo, Poirson and Ricci [24] estimated that the threshold value when external debt has a harmful effect on growth is in the range of $35-40 \%$ of GDP for the considered panel of developing countries.

In the same vein, Kumar and Woo [19] found in their empirical study that there was an inverse relationship between the initial level of government debt and the subsequent GDP growth behavior based on panel data of 38 developed and emerging economics countries over a period 
spanning around four decades (1970-2010). Qureshi and Ali [25] came to the same conclusion from their study of the Pakistanian economy between 1981 and 2008, which showed that the high level of public debt had negatively affected the economic growth. One of the important and recent researches, which chiefly address the issue of government debt at the international scale, is the study of Reinhart and Rogoff [26]. In their paper, the authors investigated the impact of different levels of public debt on the long-term real GDP growth rate by considering a heterogeneous sample of 20 developed and 24 emerging countries over a period of almost 200 years between 1790 and 2009. They also confirmed a nonlinear relationship between debt and growth by finding that below the level of $90 \%$ of GDP, public debt has a positive, but a weak impact on the long-term GDP growth rate, while the impact of debt above $90 \%$ is negative and significant.

To recapitulate, the current literature on this topic illustrates that the relationship between government debt and economic growth is nonlinear and concave (an inverted U-shape) $[18,19,20]$. This involves that public debt can either have a positive or negative effect on economic growth depending on the level of debt. Besides, the literature review discloses that the academic literature on the relationship between public debt on economic growth in developing countries, particularly in Tunisia is limited and that there is not enough consensus on this topic. In contrast with prior studies, the focus of our study is to investigate the short and the long run causality effect of public debt on economic growth in Tunisia.

\section{Data and Methodology}

For this study, we use annual data covering the period 1990-2013 obtained from different sources: the World Development Indicator (WDI 2013) database as provided by the World Bank and a set of official statistics from the Tunisian Central Bank (2013) and the Tunisian ministry of finance. The empirical analysis included real gross domestic product per capita (GDP), Public debt (PD) as a percentage of GDP, Total Debt Service (TDS) as a percentage of exports, Investment (INV) as a percentage of GDP and Export of goods and services (EXP) as a percentage of GDP. All the variables are transformed into a natural logarithmic form.

Based on the theoretical arguments the relationship between economic growth, public debt, total public service, investment and export can be specified as follows.

$$
L G D P_{t}=f\left(L P D_{t}, L T D S_{t}, L I N V_{t}, E X P_{t}\right)
$$

In this study, the Autoregressive Distributed Log (ARDL) approach developed initially by Pesaran et al. [27] will be employed for cointegration. This approach has been extensively used in empirical analysis due to its desirable properties compared to the standard Johansen cointegration technique. First, they can effectively fix potential endogeneity issues of the explanatory variables. Second, they can avoid the problems of unit root pre-testing as the test can be carried regardless of whether the series are order I(0) or order I(1). Third, the ARDL approach is appropriate for analyzing small sample size data and can estimated the long and the short run relationship together.

The ARDL bounds approach lead to estimate the following unrestricted error correction model by Ordinary Least Squares Method (OLS) :

$$
\begin{aligned}
& \Delta L G D P_{t}=\alpha_{0 G D P}+\sum_{i=1}^{n} \beta_{i G D P} \Delta L G D P_{t-i}+\sum_{i=1}^{n} \chi_{i P D} \Delta L P D_{t-i}+\sum_{i=1}^{n} \delta_{i T D S} \Delta L T D S_{t-i}+\sum_{i=1}^{n} \phi_{i I N V} \Delta L I N V_{t-i} \\
& +\sum_{i=1}^{n} \eta_{E X P} \Delta L E X P_{t-i}+\varphi_{G D P} L G D P_{t-1}+\gamma_{P D} L P D_{t-1}+\eta_{T D S} L T D S_{t-1}+\lambda_{I N V} L I N V_{t-1}+\varepsilon_{1 t} \\
& \Delta L P D_{t}=\alpha_{0 P D}+\sum_{i=1}^{n} \beta_{i P D} \Delta L P D_{t-i}+\sum_{i=1}^{n} \chi_{G D P} \Delta G D P_{t-i}+\sum_{i=1}^{n} \delta_{i T D S} \Delta L T D S_{t-i}+\sum_{i=1}^{n} \phi_{i I N V} \Delta L I N V_{t-i} \\
& +\sum_{i=1}^{n} \eta_{E X P} \Delta L E X P_{t-i}+\varphi_{G D P} L G D P_{t-1}+\gamma_{P D} L P D_{t-1}+\eta_{T D S} L T D S_{t-1}+\lambda_{I N V} L I N V_{t-1}+\varepsilon_{2 t} \\
& \Delta L T D S_{t}=\alpha_{0 T D S}+\sum_{i=1}^{n} \beta_{i T D S} \Delta L T D S_{t-i}+\sum_{i=1}^{n} \chi_{G D P} \Delta G D P_{t-i}+\sum_{i=1}^{n} \delta_{i P D} \Delta L P D_{t-i}+\sum_{i=1}^{n} \phi_{i I N V} \Delta L I N V_{t-i} \\
& +\sum_{i=1}^{n} \eta_{E X P} \Delta L E X P_{t-i}+\varphi_{G D P} L G D P_{t-1}+\gamma_{P D} L P D_{t-1}+\eta_{T D S} L T D S_{t-1}+\lambda_{I N V} L I N V_{t-1}+\varepsilon_{3 t} \\
& \Delta L I N V_{t}=\alpha_{0 I N V}+\sum_{i=1}^{n} \beta_{I N V} \Delta I N V_{t-i}+\sum_{i=1}^{n} \chi_{G D P} \Delta G D P_{t-i}+\sum_{i=1}^{n} \delta_{i P D} \Delta L P D_{t-i}+\sum_{i=1}^{n} \phi_{i I N V} \Delta L T D S_{t-i} \\
& +\sum_{i=1}^{n} \eta_{E X P} \Delta L E X P_{t-i}+\varphi_{G D P} L G D P_{t-1}+\gamma_{P D} L P D_{t-1}+\eta_{T D S} L T D S_{t-1}+\lambda_{I N V} L I N V_{t-1}+\varepsilon_{3 t}
\end{aligned}
$$




$$
\begin{aligned}
& \Delta L E X P_{t}=\alpha_{0 E X P}+\sum_{i=1}^{n} \beta_{E X P} \Delta L E X P_{t-i}+\sum_{i=1}^{n} \chi_{G D P} \Delta G D P_{t-i}+\sum_{i=1}^{n} \delta_{i P D} \Delta L P D_{t-i}+\sum_{i=1}^{n} \phi_{i I N V} \Delta L T D S_{t-i} \\
& +\sum_{i=1}^{n} \eta_{I N V} \Delta L I N V_{t-i}+\varphi_{G D P} L G D P_{t-1}+\gamma_{P D} L P D_{t-1}+\eta_{T D S} L T D S_{t-1}+\lambda_{I N V} L I N V_{t-1}+\varepsilon_{3 t}
\end{aligned}
$$

Where the $\Delta$ is the first difference and $\varepsilon_{j t},(j=1,2,3,4,5)$ are white noise error terms.

The test of the existence of cointegration relationship between variables from Eqs. 2 to 6 is done by testing the significance of the lagged levels of variables using the F-statistic. The hypothesis of no cointegration are defined by $\left(H_{0}: \varphi_{G D P}=\gamma_{P D}=\eta_{T D S}=\lambda_{I N V}=0\right)$ against the alternative hypothesis of a long run cointegration relationship $\left(H_{1}: \varphi_{G D P} \neq \gamma_{P D} \neq \eta_{T D S} \neq \lambda_{I N V} \neq 0\right)$.

Following Pesaran and al [27] the F-statistic used for this test has a non-standard asymptotic distribution and generated two sets of critical values bounds. One set assumes that all variables are integrated of order zero, $\mathrm{I}(0)$ and the other assumes they are all integrated of order one, I(1). If the computed F-statistic exceeds the higher critical bound, then the null hypothesis of the no cointegration is rejected and we can conclude that there is evidence of a long-run relationship. If it falls below the lower critical value, we do not reject the null hypothesis of no co integration. Finally, if the F-statistic is between the lower and higher critical bounds, the result is not conclusive.

The empirical analysis will be based on a three steps. The first is to verify the integration order of the variables using $\mathrm{ADF}$ and PP unit root tests. The second step is to examine the long-run equilibrium relationships among the variables. On the third step, we employed the Granger causality test to estimate the causal relationships between economic growth, public debt, total debt service, investment and export in Tunisia.

\section{Empirical Results}

\subsection{Descriptive Statistics}

Table 1 shows some descriptive statistics of some variables in the natural logarithm form over the 1990-2013 period. The summary statistics include the means, Standard-deviation, maximum and the minimum.

Table 1. Descriptive statistics

\begin{tabular}{ccccc}
\hline & Mean & Std Dev & Min & Max \\
\cline { 2 - 5 } LGDP & 7.949 & 0.22 & 7.617 & 8.275 \\
LPD & 3.958 & 0.122 & 3.706 & 4.108 \\
LTDS & 2.762 & 0.314 & 2.063 & 3.296 \\
LINV & 3.176 & 0.073 & 3.05 & 3.336 \\
LEXP & 3.776 & 0.104 & 3.637 & 4.028 \\
\hline
\end{tabular}

\subsection{Unit Root Test}

The first step before the analysis of cointegration and causality is to verify the hypothesis of non-stationary. In this study two types of unit root tests are applied. Augmented Dickey-Fuller (ADF), Phillips-Perron (PP). The results presented in table (2) show that all variables are no stationary in their level, but stationary in their first difference. The exception is total debt service (TDS) and investment (INV) which seem to be stationary respectively at the level using Phillips-Perron and Augmented Dickey-Fuller tests.

Table 2. Unit root test

\begin{tabular}{ccccc}
\hline & \multicolumn{2}{c}{ ADF } & \multicolumn{2}{c}{ PP } \\
\cline { 2 - 5 } & Intercept & $\begin{array}{c}\text { Intercept } \\
\text { and trend }\end{array}$ & Intercept & $\begin{array}{c}\text { Intercept and } \\
\text { trend }\end{array}$ \\
\hline LGDP & -0.718 & -1.715 & -0.500 & -1.953 \\
DLGDP & $-2.731^{* *}$ & $-3.651^{* *}$ & $-4.382^{*}$ & $-4.315^{* *}$ \\
LPD & -0.950 & -1.372 & -0.916 & -2.078 \\
DLPD & $-3.88^{*}$ & $-3.812^{* *}$ & $-5.320^{*}$ & $-5.164^{*}$ \\
LTDS & -1.71 & -2.914 & -1.725 & $-3.514^{* * *}$ \\
DLTDS & $-4.304^{*}$ & $-4.285^{* *}$ & $-7.895^{*}$ & - \\
LINV & -1.938 & $-4.420^{* *}$ & -1.381 & -2.281 \\
DLINV & $-3.721^{* *}$ & - & $-3.347^{* *}$ & $-3.376^{* * *}$ \\
Critical & & & & \\
value & & & & \\
$1 \%$ & -3.76 & -4.44 & -3.75 & -4.41 \\
$5 \%$ & -3.00 & -3.63 & -2.99 & -3.62 \\
$10 \%$ & -2.64 & -3.25 & -2.63 & -3.24 \\
\hline
\end{tabular}

Note: D indicates variables in first difference

* indicate significance at $1 \%, * *$ indicates significance at $5 \%, * * *$ indicates significance at $10 \%$

\subsection{ARDL Cointegration Test}

The first step of the ARDL cointegration test procedure is to select the optimal lag using the Akaike information criterion (AIC) and Schwarz information criterion (SC). The result indicates that the optimal lag length is two (2). The second step is to test the existence of the cointegration relationship among the variables using the bounds F-statistic developed by Narayan [28]. The results are reported in table 3.

When the real gross domestic product (GDP) is the dependent variable, there is a cointegration relationship among the variables of the fact that the computed F-statistics (6.26) is higher than the upper critical value (4.61) at the 5\% significance level. Also, when public debt is assigned as dependent variable, the corresponding F-statistics are above 
the critical values, suggesting the presence of long-run equilibrium relationships. The result is the same when the total debt service is a dependent variable. However, when the dependant variable is the investment (export) there is no cointegration relation among variables, the F-statistic is less than lower critical value.

Table 3. Bounds cointegration test - ARDL approach

\begin{tabular}{|c|c|c|}
\hline Equation used (1-4) & \multicolumn{2}{|c|}{ F-statistics } \\
\hline $\begin{array}{c}\text { F }_{\text {LGDP }}(\text { LGDP/LPD, LTDS, LINV, } \\
\text { LEXP) }\end{array}$ & \multicolumn{2}{|c|}{$6.26^{*}$} \\
\hline $\begin{array}{c}\mathrm{F}_{\mathrm{LPD}}(\mathrm{LPD} / \mathrm{LGDP}, \mathrm{LTDS}, \mathrm{LINV}, \\
\text { LEXP) }\end{array}$ & \multicolumn{2}{|c|}{$4.88^{*}$} \\
\hline $\begin{array}{c}\text { F }_{\text {LTDS }}(\text { LTDS/LGDP, LPD, LINV, } \\
\text { LEXP) }\end{array}$ & \multicolumn{2}{|c|}{$16.24 *$} \\
\hline $\begin{array}{c}\text { F LINV }(\text { LINV/LGDP, LPD, LTDS, } \\
\text { LEXP) }\end{array}$ & \multicolumn{2}{|c|}{2.86} \\
\hline $\begin{array}{c}\mathrm{F}_{\mathrm{LEXP}}(\mathrm{LEXP} / \mathrm{LGDP}, \mathrm{LPD}, \mathrm{LTDS}, \\
\text { LINV) }\end{array}$ & \multicolumn{2}{|c|}{1.76} \\
\hline Critical value of F-statistic & $\mathrm{I}(0)=3.88$ & $\mathrm{I}(1)=4.61$ \\
\hline
\end{tabular}

Critical values for $\mathrm{K}=2$, at $5 \%$.

We now proceed to estimate the long-run relationship between variables using the ARDL model. The results of estimation are reported in Table 4. When the real gross domestic product is a dependent variable, coefficient associated with public debt is negative and statistically significant. That implies that higher public debt is reducing the long-run economic growth in Tunisia. In fact, an increase in the public debt by $1 \%$ decreases the economic growth in the long-run by approximately the same percentage $(0.99 \%)$. This finding can be explained in the context of Tunisia where most of public debt is utilized in consumption expenditure but not in forming productive capital. Also, the total debt service payment has a negative and significant effect on economic growth in the long-run. The payment of a higher debt service could prevent a country to devote sufficient resources to productive activities. These results confirm the work of Pattillo et al [28], which showed that the impact of this variable on economic growth is either insignificant or negative and significant.

The estimated coefficient of regression shows that investment has a positive and statistically significant effect on economic growth. This finding shows, as expected, the key role of investment in economic development in Tunisia. Although theoretically export is found to be positively related to economic growth, the results reveal no significant relationship between the two variables.

Table 4. Long run estimates

\begin{tabular}{ccc}
\hline & & Coefficient (p. value) \\
\hline Dependent & Constant & $15.59 *(0.000)$ \\
variable is GDP & LPD & $-0.99 *(0.004)$ \\
& LTDS & $-0.22 * *(0.014)$ \\
LEXP & $-0.21(0.348)$ \\
LINV & $0.66 *(0.009)$ \\
\hline
\end{tabular}

$*$ indicate significance at $1 \%, * *$ indicates significance at $5 \%$.

We present now the results of the Granger causality analysis using the vector error correction (VECM). The model incorporates the first difference terms and an error correction term and is indicated in the following equations:

$$
\begin{aligned}
& \Delta L G D P_{t}=\alpha_{0 G D P}+\sum_{i=1}^{n} \beta_{i G D P} \Delta L G D P_{t-i}+\sum_{i=1}^{n} \chi_{i P D} \Delta L P D_{t-i}+\sum_{i=1}^{n} \delta_{i T D S} \Delta L T D S_{t-i}+\sum_{i=1}^{n} \phi_{i I N V} \Delta L I N V_{t-i} \\
& +\sum_{i=1}^{n} \eta_{E X P} \Delta L E X P_{t-i}+\lambda E C T_{t-1}+v_{1 t}(7) \\
& \Delta L T D S_{t}=\alpha_{0 T D S}+\sum_{i=1}^{n} \beta_{i T D S} \Delta L T D S_{t-i}+\sum_{i=1}^{n} \chi_{G D P} \Delta G D P_{t-i}+\sum_{i=1}^{n} \delta_{i P D} \Delta L P D_{t-i}+\sum_{i=1}^{n} \phi_{i I N V} \Delta L I N V_{t-i} \\
& +\sum_{i=1}^{n} \eta_{i E X P} \Delta L E X P_{t-i}+\lambda E C T_{t-1}+v_{3 t}(9) \\
& \Delta L I N V_{t}=\alpha_{0 T D S}+\sum_{i=1}^{n} \beta_{I N V} \Delta I N V_{t-i}+\sum_{i=1}^{n} \chi_{G D P} \Delta L G D P_{t-i}+\sum_{i=1}^{n} \delta_{i P D} \Delta L P D_{t-i}+\sum_{i=1}^{n} \phi_{i I N V} \Delta L T D S_{t-i} \\
& +\sum_{i=1}^{n} \eta_{i E X P} \Delta L I N V_{t-i}+\lambda E C T_{t-1}+v_{4 t}(10) \\
& \Delta L E X P_{t}=\alpha_{0 E X P}+\sum_{i=1}^{n} \beta_{E X P} \Delta L E X P_{t-i}+\sum_{i=1}^{n} \chi_{G D P} \Delta L G D P_{t-i}+\sum_{i=1}^{n} \delta_{i P D} \Delta L P D_{t-i}+\sum_{i=1}^{n} \phi_{i I N V} \Delta L T D S_{t-i}+ \\
& +\sum_{i=1}^{n} \eta_{i I N V} \Delta L I N V_{t-i}+\lambda E C T_{t-1}+v_{5 t}(11)
\end{aligned}
$$


Where $\lambda$ is the speed of the adjustment equilibrium parameter. The error correction term which is a residual term obtained by running the long term cointegration equation (1).

The results of the Granger causality test are reported in table 5. We can side that in the long-run there is a Granger causality between public debt, total debt service, investment, export and real gross domestic product. However, there is a short-run causality running from public debt to economic growth. But, there is no evidence of short-run causality between total debt service, export, investment and economic growth. This result has been confirmed in the literature as the effect of debt service usually appears in the long run not in the short one.

The lag error term $\left(\mathrm{ECT}_{\mathrm{t}-1}\right)$ of the public debt is negative and not statistically significant. The result suggest that in the long-run there is no Granger causality running from economic growth, total debt service, investment and export to public debt. In the sort-run there is Granger causality between public debt and economic growth. But, there is no Granger causality with the other variables.

Also, the result confirms that there exists a long-run Granger causality running from economic growth, public debt, export and investment to total debt service. However, there is no short-run causality Granger between total debt service and the other variables. In the case, the hypothesis of neutrality is supported.

Table 5. Granger causality test: Wald test

\begin{tabular}{cccc}
\hline variables & DLGDP & DLPD & DLTDS \\
\hline DLGDP(-1) & - & -0.94 & -3.824 \\
& & $(0.18)$ & $(0.274)$ \\
DLGD(-2) & - & -0.88 & -3.756 \\
& $-0.237 * *$ & $(0.108)$ & $(0.225)$ \\
DLPD(-1) & $(0.047)$ & - & 1.113 \\
& $-0.151^{* * *}$ & & $(0.358)$ \\
DLPD(-2) & $(0.099)$ & - & -0.706 \\
& -0.004 & -0.061 & $(0.575)$ \\
DLTDS(-1) & $(0.889)$ & $(0.283)$ & 0.08 \\
& -0.01 & -0.05 & $(0.631)$ \\
DLTDS(-2) & $(0.749)$ & $(0.631)$ & \\
& $-0.17 * * *$ & 0.199 & \\
DLINV(-1) & $(0.05)$ & $(0.361)$ & \\
& -0.027 & -0.077 & -0.872 \\
DLINV(-2) & $(0.736)$ & $(0.715)$ & $(0.424)$ \\
& -0.07 & $-0.38 * *$ & 0.299 \\
DLEXP(-1) & $(0.309)$ & $(0.033)$ & $(0.602)$ \\
& 0.05 & 1.967 & -0.543 \\
DLEXP(-2) & $(0.44)$ & $(0.116)$ & $(0.309)$ \\
& $-0.117^{* * *}$ & -0.273 & $-1.381 *$ \\
ECT(-1) & $(0.079)$ & $(0.309)$ & $(0.001)$ \\
Serial & & & \\
correlation LM & 0.315 & 0.007 & 0.008 \\
Test. Prob. chi & & & \\
$(2)$ & & & \\
\hline
\end{tabular}

* indicate significance at $1 \%, * *$ indicates significance at $5 \%, * * *$ indicates significance at $10 \%$.

Before estimating ARDL model, we apply diagnostics tests in order to verify the stability of the regression coefficients employing cumulative sum test (CUSUM). Fig.
$1,2,3$ shows that the critical values did not exceed the 5\% significance, implying the stability of coefficients.

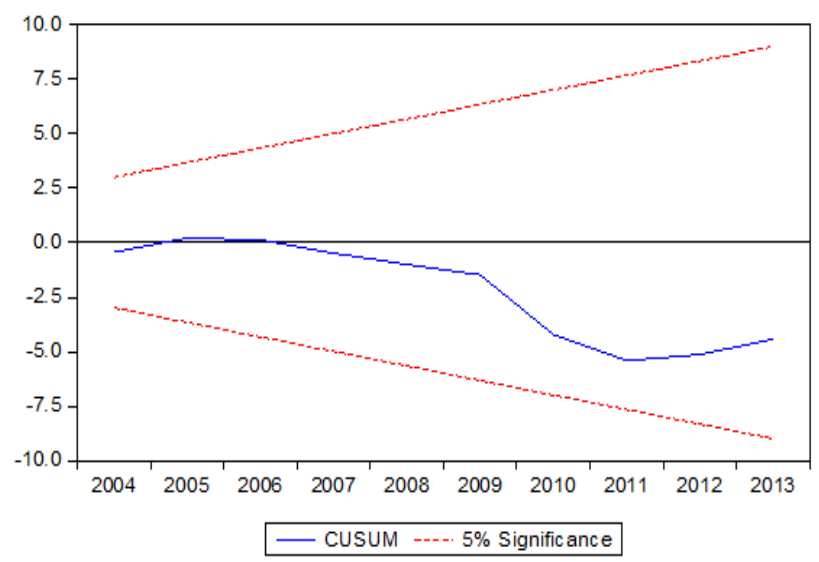

Figure 1. The straight lines represent critical bounds at $5 \%$ signific ance level

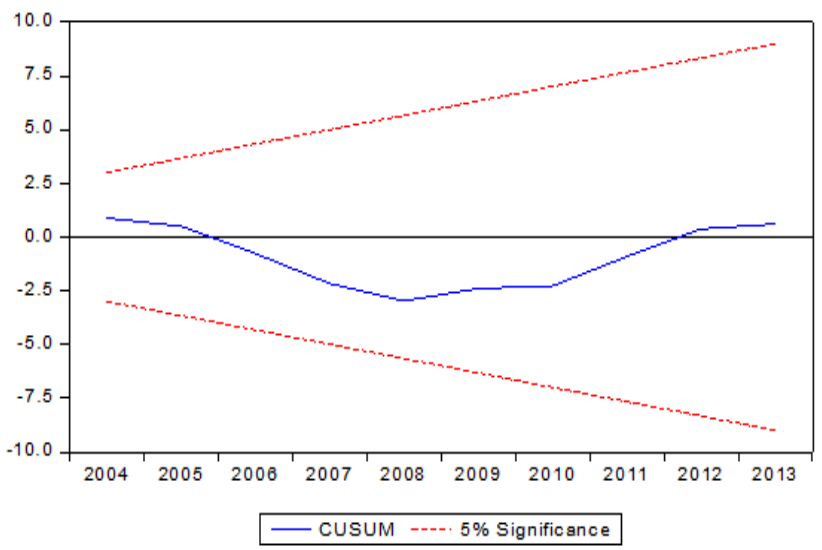

Figure 2. The straight lines represent critical bounds at $5 \%$ signific ance level

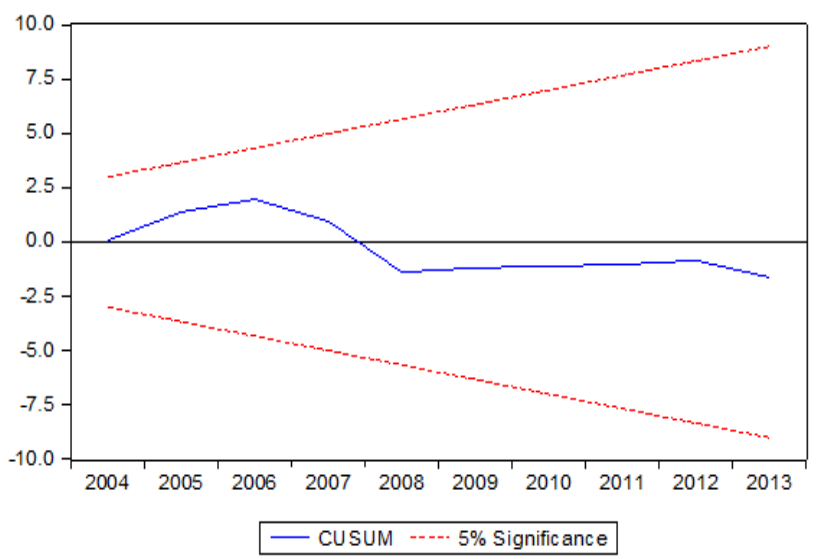

Figure 3. The straight lines represent critical bounds at $5 \%$ signific ance level

\section{Conclusion and Recommendations}

This study examined the relationship between public debt and economic growth in Tunis during the period of 
1990-2013. Our approach introduced the variables of total debt service, export and investment in the production function. The results using ARDL approach show that there is a long run relationship between public debt, total debt service and economic growth. Using the ECM model, public debt affect economic growth in the short term. Also, we concluded that there is a unidirectional granger causality between public debt and economic growth and a bidirectional causality between total debt service and economic growth in the long run. From the recommendations, the government must identify the solution for reducing the public debt, which will ultimately increase the economic growth.

\section{REFERENCES}

[1] T. Vladimir Teles and C. Mussolini. Public debt and the limits of fiscal policy to increase economic growth. European Economic Review, Vol. 66, No. 1-15, 2014.

[2] J.H. Cochrane. Understanding policy in the great recession: Some unpleasant fiscal arithmetic. European Economic Review, Vol. 55, No. 1, 2-30, 2011.

[3] Codogno et al. Yield spreads on EMU government bonds. Economic Policy, Vol. 18, 503-532, 2003.

[4] T. Laubach, (2009). New evidence on the interest rate effects of budget deficits and debt. Journal of the European Economic Association, Vol. 7, No. 4, 858-885, 2009.

[5] J.B. Delong and L.H. Summers. Fiscal Policy in a Depressed Economy. Brookings Papers on Economic Activity, 233-297, 2012.

[6] A. Schclarek. Debt and economic growth in developing and industrial countries. www.nek.lu.se/nekasc. (2004).

[7] K. Forslund, L. Lima, and U. Panizza, The determinants of composition of public debt in developing and emerging market countries. Review of Development finance, Vol. 1, 207-222. 2011

[8] C. Checherita, , P. Rother. The impact of high and growing government debt on economic growth: an empirical investigation for the Euro area. Euro Central Bank Working Paper, 1237. 2010.

[9] A. Smith. The wealth of Nations. New York: The Modern Library. 1776.

[10] D. Ricardo. On the principles of political economy and taxation. In: Sraffa, P. (Ed.), The Works and Correspondence of David Ricardo 1. Cambridge University Press, Cambridge, with the collaboration of M. Dobb. 1951.

[11] M. Abbas, and J.E. Christensen. The Role of Domestic Debt Markets in Economic Growth: An Empirical Investigation for Low-income Countries and Emerging. IMF Working Paper 07/127, Washington, DC: IMF. 2007.
[12] R. Baro. (1989). The Ricardian approach to budget deficit. Journal of Economic Perspectives, Vol. 3, 37-54. 1989.

[13] R. Camen and K. Rogoff. From financial crash to debt crisis. American Economic Review. 101, 1676-1706. 2011.

[14] M. Ismihan and F.G. Ozkan. Public debt and financial development: a theoretical exploration. Economics Letters, Vol. 115, 348-351. 2012.

[15] C. Westphal-Checherita and P. Rother. The impact of high government debt on economic growth and its channels: an empirical investigation for the Euro area. European Economic Review, Vol. 56, 1392-1405. 2012.

[16] S.G. Cecchetti, M. S. Mohanty, and F. Zampolli. The Real Effects of Debt. Working Papers, No. 352, Basel: Bank for International Settlements. 2011.

[17] C. Checherita and P. Rother. The impact of high and growing government debt on economic growth: an empirical investigation for the Euro area. Euro. Central Bank Working Paper, 1237. 2010.

[18] B. Clements, R. Bhattacharya, and T.Q. Nguyen. External Debt, Public Investment and Growth in Low-income Countries. IMF Working paper, 03/249, Washington, DC: IMF. 2003.

[19] M.S. Kumar and J. Woo. Public Debt and Growth. IMF Working Paper, 10/174, Washington, DC: IMF. (2010).

[20] C. M. Reinhart and K. S. Rogoff. Growth in a time of debt (digest summary). American Economic Review, Vol. 100, No 2, 573-578. 2010.

[21] T. Q. Nguyen, M. B. J. Clements and M. R. Bhattacharya. External debt, public investment, and growth in low-income countries. International Monetary Fund. No. 3-249. 2003

[22] P. Krugman. Financing vs. Forgiving a Debt Overhang: Some Analytical Issues. NBER Working Paper, No. 2486, Cambridge, MA: National Bureau of Economic Research. 1988.

[23] C.A. Pattillo, H. Poirson and R. Ricci. External debt and growth. IMF Working Paper, 02/69. 2002.

[24] C.A. Pattillo, H., Poirson and R. Ricci. What are the channels through which external debt affects growth? IMF Working Paper, 04/15. 2004.

[25] M.N. Qureshi, K. Ali. (2010). Public debt burden and economic growth: evidence from Pakistan. Journal of Finance and Economics. 53, 100-108. 2010.

[26] C.M. Reinhart, and K.S. Rogoff. Growth in a Time of Debt. American Economic Review, Vol. 100, No 2, pp. 573-578. 2010a.

[27] H.M. Pesaran, Y.Shin, and R.J. Smith. Bounds test approaches to the analysis of level relationships. Journal of Applied Econometrics, 16, 289-326. 2001.

[28] P.K. Narayan. The saving and investment nexus for China: evidence from cointegration tests. Applied Economics. Vol. 37, 1979-1990. 2005. 